\title{
Current State and Performance Review of SEZs in India: A Survey
}

S P Sharma*, Rashmi Taneja** and Apurva Munjal***

\begin{abstract}
The establishment of the India's first Special Economic Zones (SEZ) unit and the consequent announcement of a comprehensive SEZs Act in February 2006, bestowed a number of benefits to SEZs in terms of fiscal incentives and state of art infrastructure. Since then SEZs have witnessed generation of employment, investments and exports over a period of time. The current survey has been undertaken to highlight the efficiency and issues of SEZs and their expectations with regard to the formulation and modification of policies. The survey reveals that while some progress has been made in the effective functioning of the SEZs, yet the expected benefits have not been reaped. High operational cost, fall in market demand, global slowdown, lack of skilled manpower are some reasons held accountable why SEZs in India have not taken off. Furthermore, it is found that operating in Domestic Tariff Area (DTA) has become more beneficial as compared to operating within SEZs especially after withdrawal of exemption for Minimum Alternate Tax (MAT) and Dividend Distribution Tax (DDT) for the SEZs. A robust policy design and efficient implementation can lead to the effective functioning of the SEZs which is an important mechanism for promoting trade and investment, along with generation of employment.
\end{abstract}

Keywords: Special Economic Zones (SEZs), Minimum Alternate Tax (MAT), Dividend Distribution Tax (DDT)

\subsection{Introduction}

Special Economic Zones (SEZs) have been recognised as an important mechanism for trade and investment promotion, creation of infrastructure, employment generation, promotion of regional development, increase in foreign exchange earnings, improving export competitiveness and transfer of skills and technology.

*Chief Economist, PHD Chamber of Commerce and Industry, New Delhi

**Senior Research Officer, PHD Chamber of Commerce and Industry, New Delhi

***Research Assistant, PHD Chamber of Commerce and Industry, New Delhi 
The SEZs have been in existence for decades, but have attracted renewed attention world-wide in recent years due to globalisation of trade and financial markets. Now, it is a well-recognised fact that the SEZs are instrumental in developing local and regional infrastructure facilities, which in turn are necessary for overall economic development of a country.

The genesis of SEZs in India lies in the basic model of EPZs ${ }^{1}$ (Export Promotion Zones) which was set-up at Kandla (KFTZ, Kandla Free Trade Zone) in Gujarat in 1965, following which five more EPZs were established in India. In 2000, the Export-Import (EXIM) Policy of India shifted towards a new scheme of Special Economic Zones (SEZs), wherein EPZs were converted into SEZs. In all, the EPZs have progressed over four distinct phases over the last five decades which are discussed briefly here below (Figure 1).

\subsection{Objectives and Research Methodology}

\subsection{Objectives}

The major objectives of the present study are (i) to understand the evolution process of SEZs in India; (ii) to analyse the current status and performance of SEZs in India in terms of investments, employment and exports; (iii) to identify the issues and challenges of SEZs developers'/units in India; (iv) to analyse the overall efficacy of the functioning and monitoring of SEZs in India and (v) to recommend the policy measures to address the concerns of SEZs developers'/units in India.

\subsection{Research methodology}

The present study is an attempt to determine the efficacy of SEZs in India from the perspectives of developers/units. For this, data are collected through primary sources whereby a survey is conducted through a structured questionnaire. The questionnaire is disseminated to about 200, SEZs inclusive of developers and units situated across India viz. Gujarat, Hyderabad, Indore, Noida etc. During this course, about 106 responses have been received which have provided the basis to determine the final results pertaining to the stated objectives of the study. Statistical averages are used to analyse the survey results.

\subsection{Current State and Performance of SEZs}

Since the promulgation of SEZs Act in 2005, the SEZs have shown mixed trends of significant achievements and shortcomings in the performance of SEZs in the country. 
The key facts relating to the current scenario and overall performance of SEZs in India is discussed below.

\section{Figure 1: Journey from EPZs to SEZs in India: Snapshot}

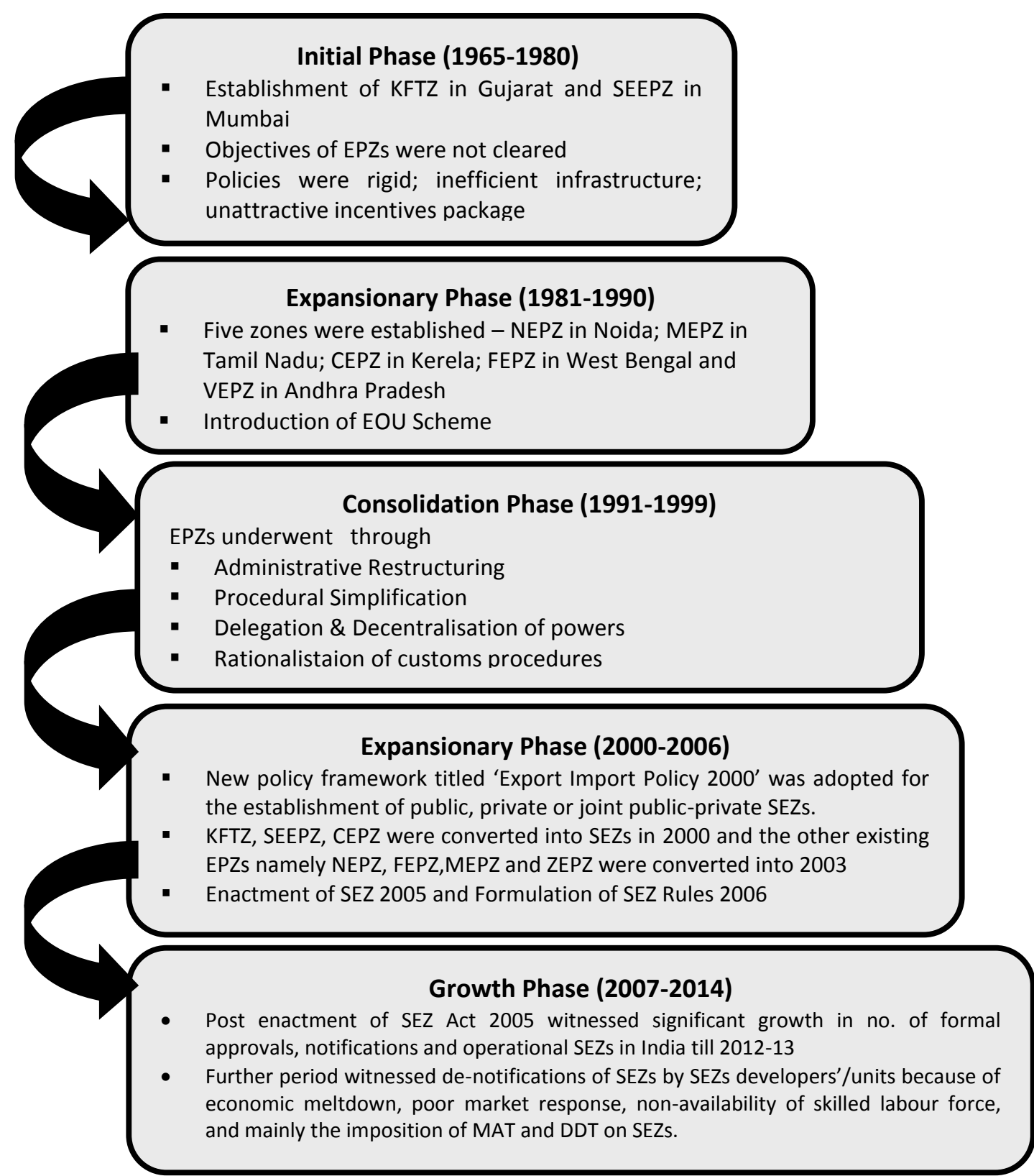




\subsection{Approved and Notified SEZs}

In a span of about eight years since the SEZs Act and Rules were notified in February 2006, formal approvals have been granted for setting up of 491 SEZs, of which 352 have been notified and 33 have been given in-principle approvals as of $5^{\text {th }}$ December, 2014. While, 196 SEZs are operational and around 3800 units are approved within the SEZs as of $30^{\text {th }}$ September, 2014 (Table 1).

Table 1: Current Status of SEZs in India

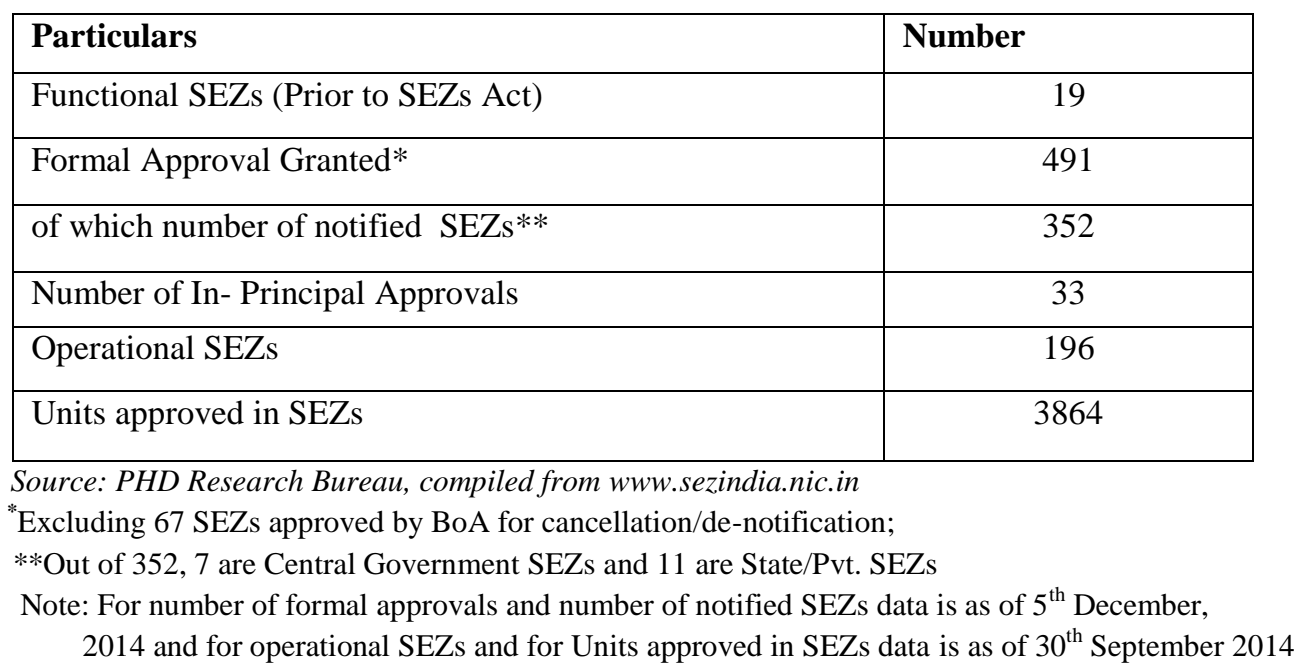

Thus, journey from EPZs to SEZs in India has witnessed several developments and failures in terms of conception of EPZs, expansion of EPZs across India, conversion of EPZs into SEZs in the light of various inefficiencies, its reintroduction under the ambit of new SEZ Act, growth of SEZs establishment in India and further loosening its significance due to imposition of MAT and DDT. While the new Government is again set to put a great emphasis on revisiting the SEZs model and making it a catalyst for India's economic growth in coming times.

\subsection{State-wise SEZs}

While one of the significant objectives of establishing an SEZ is to achieve balanced growth across all regions of the country, it is noted that 5 States, namely Maharashtra, Telangana, Karnataka, Tamil Nadu, Andhra Pradesh collectively constitute $55 \%$ of the total formal approvals, $60 \%$ of the notified SEZs and around 55\% of inprinciple approvals by the government as of December 2014 (Table 2). 
Table 2: State-wise distribution of SEZs

\begin{tabular}{|c|c|c|c|c|c|c|}
\hline States/UTs & $\begin{array}{c}\text { Formal } \\
\text { approvals } \\
(491)\end{array}$ & $\begin{array}{c}\text { Formal } \\
\text { approvals } \\
(\%)\end{array}$ & $\begin{array}{c}\text { Notified } \\
\text { SEZs } \\
(\mathbf{3 5 2})\end{array}$ & $\begin{array}{l}\text { Notified } \\
\text { SEZs } \\
(\text { in \%) }\end{array}$ & $\begin{array}{c}\text { In- } \\
\text { principle } \\
\text { approvals } \\
\text { (33) }\end{array}$ & $\begin{array}{c}\text { In- } \\
\text { principle } \\
\text { approvals } \\
\text { (in \%) }\end{array}$ \\
\hline Maharashtra & 69 & 14.1 & 52 & 14.8 & 9 & 27.3 \\
\hline Telangana & 60 & 12.2 & 42 & 11.9 & 0 & 0 \\
\hline Karnataka & 59 & 12 & 39 & 11.1 & 0 & 0 \\
\hline Tamil Nadu & 55 & 11.2 & 51 & 14.5 & 5 & 15.2 \\
\hline $\begin{array}{l}\text { Andhra } \\
\text { Pradesh }\end{array}$ & 40 & 8.1 & 30 & 8.5 & 4 & 12.1 \\
\hline Gujarat & 35 & 7.1 & 28 & 8 & 4 & 12.1 \\
\hline Haryana & 34 & 6.9 & 25 & 7.1 & 3 & 9.1 \\
\hline Kerala & 32 & 6.5 & 25 & 7.1 & 0 & 0 \\
\hline $\begin{array}{l}\text { Uttar } \\
\text { Pradesh }\end{array}$ & 31 & 6.3 & 22 & 6.3 & 1 & 3 \\
\hline $\begin{array}{l}\text { Madhya } \\
\text { Pradesh }\end{array}$ & 19 & 3.9 & 9 & 2.6 & 1 & 3 \\
\hline West Bengal & 12 & 2.4 & 5 & 1.4 & 2 & 6.1 \\
\hline Rajasthan & 9 & 1.8 & 8 & 2.3 & 1 & 3 \\
\hline Others & 36 & 7.3 & 16 & 4.5 & 3 & 9.1 \\
\hline
\end{tabular}

\subsection{Sector-wise SEZs}

The sector wise distribution of SEZs clearly shows that majority of the formal approvals granted have been in IT/ITES sector which comprises nearly $75 \%$ of the total formal approvals granted till date. This can be as a result of India's growing prowess in the IT/ITES Sector and availability of trained manpower which is resulting in outsourcing of such activities to India. The high number of formal approvals of IT/ITES Sector has also resulted in a high share of such SEZs in the notified SEZs category $(61 \%)$.

Other prominent sectors include; Biotech, Textiles, Pharma, Engineering etc in addition to 21 formally approved multi-product SEZs. In terms of in-principle approvals, large multi-product SEZs have a share of more than $50 \%$ followed by textile/ biotech sectors. The SEZs BoA is not granting any in-principle approval to proposals for IT/ITES Sector. 


\subsection{Performance of SEZs and Socio-economic impact}

The three important objectives of the SEZs Act, 2005 are to generate employment opportunities, encourage investments and increase India's exports. Under this ambit performance of SEZs in India is measured in terms of employment, investments and exports.

\subsection{Employment}

Incremental employment has been observed increasing significantly from $25 \%$ in FY2009 to around 47\% in FY2011. However, incremental growth rate registered a decline to 32\% in FY2013 on account of continuous de-notification of number of SEZs as a result of several adverse market dynamics (Table 3). In a nutshell, SEZs has witnessed four-fold generation of employment from around 3 lakh persons in FY2008 to around 12 lakh persons in FY2014. However, it could not generate expected rate of employment on account of several legal and market changes.

Table 3: Employment Generation

\begin{tabular}{|l|c|c|c|c|}
\hline Year & $\begin{array}{c}\text { Incremental } \\
\text { Employment }\end{array}$ & Growth (\%) & $\begin{array}{c}\text { Cumulative } \\
\text { Employment }\end{array}$ & Growth (\%) \\
\hline FY2008 & 201531 & & 336235 & \\
\hline FY2009 & 252735 & 25.41 & 387439 & 15.23 \\
\hline FY2010 & 368907 & 45.97 & 503611 & 29.98 \\
\hline FY2011 & 541904 & 46.89 & 676608 & 34.35 \\
\hline FY2012 & 710212 & 31.06 & 844916 & 24.88 \\
\hline FY2013 & 940200 & 32.38 & 1074904 & 27.22 \\
\hline FY2014* & 1105141 & 17.54 & 1239845 & 15.34 \\
\hline
\end{tabular}

Source - PHD Research Bureau, Compiled from CAG, India

* Dlata as on $31^{\text {st }}$ December,2014

\subsection{Investments in SEZs}

Incremental investments have shown a positive growth rate over a period of time barring few years. On an average, incremental investments were increased by $40 \%$ from FY2009 to FY2011. However, FY2012 posted a negative growth rate of (-) $0.47 \%$ (Table 4). This steep fall was attributed to several legal and market dynamics in the domestic as well as international economy including rising cost of operations, global slowdown, fall in market demand, imposition of MAT and DDT in 2011, and lack of 
skilled man power. These factors eroded the viability of setting up industrial projects within the SEZs and thus negatively impacted the investors' sentiments. Though incremental investments growth rate turned positive at 18\% in FY2013 and 22\% in FY2014, yet it could not achieve the earlier levels of around $40 \%$ achieved during FY2009-FY2011. Corresponding to the incremental investments growth rate, cumulative investments growth rate also depicted the same trends. In nutshell, though investments in the SEZs increased from three fold from Rs. 77,000 cr. in FY2008 to Rs. 288,000 cr. in FY2014, however, its growth rate did not remain consistent owing to several unfavourable changes in the domestic and global market.

Table 4: Investments in SEZs

\begin{tabular}{|l|c|c|c|c|}
\hline Year & Incremental Investment & Growth (\%) & Cumulative Investment & $\begin{array}{c}\text { Growth } \\
(\%)\end{array}$ \\
\hline FY2008 & 73174 & & 77210 & \\
\hline FY2009 & 104867 & 43.31 & 108903 & 41.05 \\
\hline FY2010 & 144453 & 37.75 & 148489 & 36.35 \\
\hline FY2011 & 198774 & 37.60 & 202810 & 36.58 \\
\hline FY2012 & 197839 & -0.47 & 201875 & -0.46 \\
\hline FY2013 & 232681 & 17.61 & 236717 & 17.26 \\
\hline FY2014 & 284441 & 22.25 & 288477 & 21.87 \\
\hline
\end{tabular}

Source - PHD Research Bureau, Compiled from CAG, India

*Data as on 31st December, 2014

\subsection{Exports}

Exports from SEZs have shown a positive growth rate during the last many years. However, the exports growth remained extremely volatile from 52\% in FY2007 to $121 \%$ in FY2010 and to 43\% in FY2011. The following years also registered the declining growth rate from 15\% in FY2013 to 4\% in FY2014 (Table 5). In nutshell, though exports growth of SEZs in India remained fluctuating over the period of time, yet exports from SEZs have witnessed a significant rise of around 22 fold from Rs. 22000 crores in 2005-2006 to Rs. 5 lakh crores in 2013-14.

\subsection{Survey Results}

Our survey for reviewing the performances of SEZs in India has enabled to know the SEZs' developers/units view-points relating to overall efficiency and issues of 
SEZs and their expectations with regard to formulating and modifications of policy measures. The detailed survey results with respect to SEZs developers' viewpoints towards different aspects are discussed in the following categories.

- Experience with respect to administrative procedures

- Fixed time period

- Single Window Clearance Mechanism

- Concessions/ Exemptions availed

- Operational Stage

- Monitoring \& Control

- De-Notification \& Exit

Table 5: Exports from SEZs

\begin{tabular}{|c|c|c|}
\hline & & (Rs. Crores) \\
\hline Year & Exports from SEZs & Growth (in \%) \\
\hline $2005-2006$ & 22840 & - \\
\hline $2006-2007$ & 34615 & $52 \%$ \\
\hline $2007-2008$ & 66638 & $93 \%$ \\
\hline $2008-2009$ & 99689 & $50 \%$ \\
\hline $2009-2010$ & 220711 & $121 \%$ \\
\hline $2010-2011$ & 315868 & $43 \%$ \\
\hline $2011-2012$ & 364478 & $15 \%$ \\
\hline $2012-2013$ & 476159 & $31 \%$ \\
\hline 2013-2014 & 494077 & $4 \%$ \\
\hline
\end{tabular}

Source: PHD Research Bureau, Compiled from CAG, India

* Data as on 31st December, 2014

With respect to administrative procedures almost all the SEZs developers/units unanimously felt that, hardly there is any significant export benefits are left to operate within the SEZs in India over to operate within its DTAs. However, on the administrative processes and procedures almost all of the respondents' experiences with respect to different processes for getting approvals for setting up SEZs are quite satisfactory.

The survey that with respect to prescribe the fixed time period for different processes, almost all the respondents(90\%) felt that a fixed time period needs to be prescribed for getting approval by BOA. However, in case of submission of documents by developers for getting notifications; for notifying the SEZs by Central Government, for submission of half-yearly and quarterly return by the developers; for granting of NOC from various authorities for exiting from SEZ scheme and for approval of exit 
when NOCs and DC certificate are submitted, around $75 \%$ of the respondents felt that there is need to prescribe a fixed time period.

Relating to Single Window Clearance Mechanism, about 36\% of the respondents reported that single window clearance mechanism exists in their respective States Rest of the respondents (64\%) reported that there is no single window clearance mechanism in their respective States and they are required to obtain the separate clearances from the different authorities viz. Pollution Control Board, Ministry of Environment \& Forest, Police Station and others. With regards to existence to SWCM, 64\% of respondents have expressed the non-existence of single window clearance mechanism, but majority of the respondents $(60 \%)$ of the States where the mechanism exists reported that the mechanism integrates all the required clearances envisaged in the Act. However, $46 \%$ of the respondents reported that the clearances are not given timely.

Pertaining to concessions/exemptions availed, the survey found that $88 \%$ of the respondents avail the stamp duty exemption and with respect to discontinuation of MAT/DDT almost all the respondents (98\%) felt that MAT/DDT should be discontinued so as to keep the developers/units encouraged. The withdrawal of exemption of MAT/DDT has negatively impacted the morale of exporters within the SEZ in recent times.

They felt that operating in Domestic Tariff Area (DTA) has become more beneficial as compared to operating within SEZs especially after withdrawal of exemption for Minimum Alternate Tax (MAT) and Dividend Distribution Tax (DDT) for the SEZs. Therefore, they considered it as a big blow to the promotion of SEZs in the country. In this reference, a case of engineering industry is discussed where in duty structure and taxes in SEZ and DTA are compared to show that operating in DTA is more beneficial as compared to operating within SEZs.

The survey observed that there is a shortfall between the projections and actuals of employment/investments/exports and almost all the respondents (96\%) considered global recession as the major reason of this shortfall. Around $60 \%$ of the respondents considered lack of infrastructural facilities, end of tax holiday, too many restrictions and frequent changes in policies like Minimum Alternate Tax (MAT) as the major reasons for this shortfall. $75 \%$ of the respondents felt that cumbersome land acquisition process is not a major reason for the several instances of shortfall between the projection and actuals of exports/employment/investment.

With regards to IT/ITES SEZs constituting a major chunk of total number of SEZs in country, the survey results found that almost all respondents $(90 \%)$ felt that short turnaround time and end of tax holiday in STP (Software Technology Park) are the major reason for this trend. Most of the respondents( $80 \%)$ felt that availability of skilled 
manpower, availability of plug and play facilities and involvement of less investment and huge global market for the IT sector are the other significant reasons of its concentration in SEZs in India.

With respect to monitoring and control, almost all the respondents (95\%) are satisfied the most with the sufficient time given for submitting APRs. Most of the respondents $(87 \%)$ considered present format of APRs relevant and user-friendly; however $40 \%$ of the respondents reported redressal of grievances by UAC/BOA inefficient and unsatisfactory.

Pertaining to de-notification and exit and loan raised, the survey found that $20 \%$ have applied for exit from scheme and that is mainly because of poor global market situation in recent times. The respondents also felt that operating in DTA has become more beneficial as compared with operating within SEZ especially after withdrawal of exemption from MAT and DDT. Most of the respondents (83\%) reported that that they did not have to raise any loan against the land allotted for SEZ.

\subsection{Conclusion}

SEZs in India have witnessed generation of employment, investments and exports over a period of time; however, it is considered that the SEZs model in India could not reap the expected benefits pertaining to all these aspects. The underlying reasons which are found while conducting secondary analysis and primary survey are rise in cost of operation, global slowdown, fall in market demand, lack of skilled manpower and imposition of MAT and DDT. Therefore, it is considered that SEZs model in India could never take off in the country.

Pertaining to different stated aspects of the survey, several positive and negative facts are observed and analysed. The major change which is observed is change in SEZs developers/units pessimistic attitude towards SEZs concept in India. The respondents feel that being operational in DTA is becoming more beneficial as compared to operating within SEZs. This is on account of enhancing several export incentives for the exporters operating within DTA which finally acted as a disincentive for the exporters operating within SEZ.

Though SEZs have resulted in positive outcomes in the country in terms of employment, exports and investments, yet the concept of SEZs in India is critically argued because of several other burgeoning issues. The foremost issue which overshadows the positive results of SEZs in India is acquisition of farmland for establishing SEZs in the country. The other issue is related to the concentration of SEZs in the districts that are relatively more industrialised or situated in sea connected States, 
creates regional imbalances and income inequality and thus undermine the objective of promotion of balanced regional development in the country. With regard to overall functioning of the SEZs, getting permission from the custom authorities for procuring/exporting materials/services and getting sanction of claims viz. rebate, CST are considered to be the major difficulties. Also, non-existence of single window clearance system widely and lack of clarity in certain procedures such as exit from the SEZs results in operational inefficiency for SEZs.

In the light of these issues, we believe that lack of a robust policy design and its efficient implementation can seriously jeopardize India's efforts to industrialise through SEZs. The response of the developers / units within SEZs mainly points towards a need for revamping single window clearance system, efficient tax administration and review of the decision to introduce DDT and MAT.

\subsection{Recommendations}

- Administrative procedures should be streamlined and made more effective, especially getting the customs clearances and sanctions of the claims.

- Timelines to be prescribed and followed strictly to reduce delays at several stages of approvals/other processes.

- Since Single Window Clearance Mechanism is one of the best practices for catalysing the business environment in India, it is imperative to review the single window system in various States to unplug the loopholes and it is for the State Government to take the proper initiatives on this issue.

- Since in most of the States, Single Window Clearance Mechanism does not exist, the government should prescribe the average time to be taken by the respective authorities to give clearances/ sanctions for electricity, water supply, land related matters etc.

- Withdrawal of MAT/DDT exemption should be discontinued and once the policy towards benefits is made then it should not be changed till "time frame" is over.

- Conducive business environment should be created for SEZs by simplifying procedures, developing state of the art infrastructure and stabilising fiscal regime.

- The overall SEZ policy should be directed towards involving all the states and sectors.

- Grievances redressal mechanism is required to be made stringent and more effective. 


\section{Endnotes}

1. An EPZ is defined "as a clearly delineated industrial estate, which constitutes a free trade enclave in the customs and trade regime of a country and where foreign manufacturing firms producing mainly for export benefit from a certain number of fiscal and financial incentives" (World Bank, 1981).

\section{References}

Aggarwal, A. (2006). Special Economic Zones: Revisiting the Policy Debate. Economic and Political Weekly, 4533-4536.

Aggarwal, A. (2010). Economic impacts of SEZs: Theoretical approaches and analysis of newly notified SEZs in India. Munich Personal RePEc Archive (MPRA) Paper No. 20902. Available online at http://mpra.ub.uni-muenchen.de/20902/

Comptroller and Auditor General of India. (2014). Performance of Special Economic Zones (SEZs). Report of the Comptroller and Auditor General of India, No 21 of 2014. Union Government, Department of Revenue-Indirect Taxes-Customs.

Kundra, A. (2000). The Performance of India's Export Zones. A Comparison with Chinese Approach. Sage Publications, New Delhi.

Lakshmanan, L. (2009). Evolution of Special Economic Zones and Some Issues: The Indian Experience. Reserve Bank of India Staff Studies.

Mansingh, P. et al. (2012). Trade Unions and Special Economic Zones in India. Centre for Education and Communication (CEC), New Delhi for the ILO Bureau for Workers' Activities (ACTRAV). International Labour Office.

Ministry of Law and Justice (Legislative Department). (2005). The Special Economic Zones Act. Part II- section I . The Gazette of India.

Mukhopadhyay, P. et. al. (2009). Special Economic Zones: Promise, performance and pending issues. CPR Occasional Paper Series. Centre for Policy Research. 
88 | FOCUS: Journal of International Business, Vol. 2, Issue 1

Singala, S. Atmavilas, Y. \& Singh, E. (2011). Special Economic Zones in India: Policies, Performance and Problems. ASCI Journal of Management 40(2): 21-59.

Thothathri, A. \& Parag, D. (2002). Free Trade Zones to Special Economic Zones: The Great Indian Dream. Pentagon Press, New Delhi 